\title{
Sex Pili as Immunogens
}

\author{
By H. WILLIAMS SMITH AND M. B. HUGGINS \\ Houghton Poultry Research Station, Houghton, Huntingdon, Cambs. PE $172 D A$
}

(Received 30 December 1974; revised 12 February 1975)

SUMMARY

Groups of chickens were vaccinated intravenously with live cultures of Escherichia coli $\mathrm{KI} 2$ possessing transfer factors $\mathrm{F}, \mathrm{I}, \mathrm{A2}$ or no transfer factor (Tra-) and their immunity challenged by injecting them intravenously with an $\mathrm{F}^{+}$strain of Salmonella heidelberg or an $\mathrm{F}^{+}$or $\mathrm{I}^{+}$strain of Salmonella typhimurium. Compared with the $\mathrm{Tra}^{-}$strain, vaccination with the $\mathrm{F}^{+}$, but not the $\mathrm{I}^{+}$or $\mathrm{A2}_{2}^{+}, \mathrm{KI} 2$ strain significantly reduced the mortality rate caused by the $\mathrm{F}^{+}$salmonella strains; vaccination with the $\mathrm{I}^{+}$or $\mathrm{A2}^{+}$, but not the $\mathrm{F}^{+}, \mathrm{KI} 2$ strain significantly reduced the mortality rate caused by the $\mathrm{I}^{+}$salmonella strain.

\section{INTRODUCTION}

Following the initial observation of Ørskov \& Ørskov (I960) that agglutinating antibodies can be produced against the sex pili determined by transfer factor $F$, sex pilus antibody has been demonstrated by other techniques. These include direct observation by electron microscopy of the attachment of antibody molecules to the pili. Using this technique, Lawn \& Meynell (1970) distinguished four serotypes in the F-like class of pili and two in the Ilike class. The validity of their classification was confirmed by Harden \& Meynell (1972), employing a method that depended on the ability of pilus antibody to inhibit genetic transfer in a specific manner. The present communication is concerned with sex pili as immunogens. Chickens were vaccinated with live cultures of Escherichia coli KI2 possessing one or other of three highly efficient transfer factors: F (Lederberg, Cavalli \& Lederberg, I952; Hayes, 1953), I (IdrdI6; Hardy et al. 1973) and A2 (Smith \& Heller, I973). Their immunity against salmonella strains in which $F$ or I had been established was then challenged. It was difficult to prepare suitable challenge strains, because cultures had to contain enough piliated bacteria for them to be susceptible to visible lysis by pilus-specific phages - the MS2 phage (Davis, Strauss \& Sinsheimer, I96I) in the case of $\mathrm{F}^{+}$strains and the If I phage (Meynell \& Lawn, I968) in the case of $\mathrm{I}^{+}$strains. Some of the strains satisfying this criterion exhibited too great a reduction in pathogenicity; in others, the transfer factors were unstable. Eventually an $\mathrm{F}^{+}$strain of Salmonella heidelberg and an $\mathrm{I}^{+}$strain of Salmonella typhimurium (phage type 36 ) were obtained which appeared suitable. An $\mathrm{F}^{+}$form of the $S$. typhimurium strain was also used in some experiments although cultures of this strain were not lysed so completely by the MS2 phage as were cultures of the $\mathrm{F}^{+} S$. heidelberg strain.

\section{METHODS}

Bacterial strains and cultural conditions. Unless stated, in none of the E. coli or salmonella strains employed had either transfer factors or known transmissible characters been detected. Cultures were maintained on Dorset's egg medium at $5{ }^{\circ} \mathrm{C}$. When required as broth cultures they were inoculated into $10 \mathrm{ml}$ nutrient broth (Oxoid No. 2) in I oz Universal containers and incubated at $37^{\circ} \mathrm{C}$ for $24 \mathrm{~h}$ in a sloped position. The cultures contained approximately $10^{9}$ viable organisms $/ \mathrm{ml}$. 
Preparation of vaccinal and challenge strains. The vaccinal strains were prepared by establishing F, I and A2 in a nalidixic acid-resistant mutant (nal ${ }^{r}$ ) of a lac $^{-}$auxotrophic $E$. coli KI2 strain. Proof of establishment was susceptibility to the F-specific phage, MS2, or the I-specific phage, IfI, in the case of the $\mathrm{F}^{+}$and $\mathrm{I}^{+}$strains, and ability to mobilize resistance determinants by the technique of Smith \& Linggood (I970) in the case of the $\mathrm{A2}^{+}$ strain. For the preparation of challenge strains, auxotrophic $E$. coli $\mathrm{KI}_{2} \mathrm{~F}^{+} \mathrm{Tet}^{+}$and $\mathrm{I}^{+} \mathrm{Tet}^{+}$ strains were first prepared by using $\mathrm{F}$ and I to mobilize Tet in a Tra- E. coli KI 2 strain and to transfer it to the $n a l^{\mathrm{r}} \mathrm{KI} 2$ strain (Tet, tetracycline resistant determinant described by Smith \& Gyles, 1970; Tra, transfer factor). The auxotrophic $E$. coli $\mathrm{KI}_{2} \mathrm{~F}^{+} \mathrm{Tet}^{+}$strain and a $S$. heidelberg strain were then grown together in nutrient broth, the mixed culture centrifuged and the deposit inoculated on to plates of medium containing $(\mathrm{g} / \mathrm{l}): \mathrm{K}_{2} \mathrm{HPO}_{4}, 7$; $\mathrm{KH}_{2} \mathrm{PO}_{4}, 3$; $\left(\mathrm{NH}_{4}\right)_{2} \mathrm{SO}_{4}$, I; $\mathrm{MgSO}_{4} .7 \mathrm{H}_{2} \mathrm{O}, 0 . \mathrm{I} ; \mathrm{NaCl}, 5$; glucose, 5; agar, 15 ; and tetracycline, 0.020 . Colonies of $S$. heidelberg isolated on this medium after incubation at $37^{\circ} \mathrm{C}$ for $48 \mathrm{~h}$ were purified by replating. From these, broth cultures were prepared and a loopful spread evenly over small areas of plates of tryptose agar (Difco). A drop of an undiluted preparation of phage MS2 was placed on each dried, inoculated area. After incubation for $8 \mathrm{~h}$ at $37^{\circ} \mathrm{C}$, the plates were examined for phage lysis. The parent broth cultures of those tryptose agar cultures that appeared to have been completely lysed and that were smooth as judged by the acriflavine slide test (Braun \& Bonestell, 1947) were examined further, to find one that was lethal for chickens and that was still fully susceptible to the MS2 phage when isolated from chickens it had killed. An $\mathrm{F}^{+} \mathrm{Tet}^{+}$strain of S. typhimurium was prepared in a similar manner to the $\mathrm{F}^{+} \mathrm{Tet}^{+}$strain of $S$. heidelberg, the particular strain selected being slightly less susceptible to the MS2 phage than the $S$. heidelberg strain. An $\mathrm{I}^{+}$challenge strain was prepared from the $S$. typhimurium strain in the same manner as the $\mathrm{F}^{+}$challenge strains except that the donor strain was $\mathrm{I}^{+} \mathrm{Tet}^{+}$instead of $\mathrm{F}^{+} \mathrm{Tet}^{+}$and the phage was IfI instead of MS2.

Vaccination and challenge procedure. Groups of Light Sussex chickens from a salmonellafree flock were injected intravenously (i.v.) with $0.5 \mathrm{ml}$ broth culture of one or other of the three vaccinal strains, or of the $E$. coli KI2 strain from which they were prepared, when they were two weeks and again when three weeks of age. Thirteen days after the second injection the chickens were injected i.v. with $0.5 \mathrm{ml}$ broth culture of one of the salmonella challenge strains. A group of unvaccinated chickens was challenged at the same time. The number of chickens in each group that died on each of the first 9 days after challenge was recorded; few deaths that could be directly related to the infection occurred after this time. Samples from the livers of most of the chickens that died were cultured on plates of MacConkey's agar and ten colonies from each plate examined for susceptibility to the MS2 phage or the If phage.

Statistical analysis. The results of the lethality tests were analysed in $2 \times 2$ contingency tables and examined for significance by the $\chi^{2}$ test by Mr J. G. Rowell, A.R.C. Statistics Group, Cambridge University.

Antisera. These were prepared against the vaccinal strains by the multiple i.v. injection of rabbits with live broth cultures.

RESULTS

Mortality following infection

Compared with vaccination with the $\mathrm{Tra}^{-}$strain, vaccination with the $\mathrm{F}^{+}$strain, but not the $\mathrm{I}^{+}$or $\mathrm{A2}^{+}$strains, of $E$. coli KI 2 significantly reduced the mortality following infection with an $\mathrm{F}^{+}$strain of either $S$. heidelberg or $S$. typhimurium (Tables I and 2). Likewise, 
Table I. The effect of vaccinating chickens with an $\mathrm{F}^{+}, \mathrm{I}^{+}$or $\mathrm{A2}^{+}$strain of $\mathrm{E}$. coli $\mathrm{K} \mathrm{I} 2$ on subsequent infection with an $F^{+}$strain of $S$. heidelberg

For details, see text.

\begin{tabular}{|c|c|c|c|c|}
\hline \multirow[b]{2}{*}{ Vaccinal strain } & \multicolumn{2}{|c|}{$\begin{array}{l}\text { No. of chickens } \\
\text { vaccinated }\end{array}$} & \multicolumn{2}{|c|}{$\begin{array}{l}\text { Percentage that died } \\
\text { when infected }\end{array}$} \\
\hline & Expt. I & Expt. 2 & Expt. I & Expt. 2 \\
\hline E. coli $\mathrm{KI}_{2} \mathrm{~F}^{+}$ & 43 & 40 & $23 \cdot 3 \ddagger$ & $22.5 \dagger$ \\
\hline E. coli $\mathrm{KI}_{2} \mathrm{I}^{+}$ & - & 40 & $\longrightarrow$ & $55^{\circ} 0 \mathrm{NS}$ \\
\hline E. coli $\mathrm{KI}_{2} \mathrm{A2}^{+}$ & - & 40 & - & $70.0 \mathrm{NS}$ \\
\hline E. coli K I $2 \mathrm{Tra}^{-}$ & 39 & 40 & $64 \cdot 1$ & $60 \cdot 0$ \\
\hline None & 40 & 40 & $67.5 \mathrm{NS}$ & $95 \cdot 0 \ddagger$ \\
\hline
\end{tabular}

Significance compared with the results for the $E$. coli KI2Tra- group: NS, not significant $(P>0.05)$; *, 0.01 $<P<0.05$;, $0.001<P<0.01 ; \ddagger P<0.001$.

Table 2. The effect of vaccinating chickens with an $\mathrm{F}^{+}, \mathrm{I}^{+}$or $\mathrm{A2}^{+}$strain of E. coli on subsequent infection with an $\mathrm{F}^{+}$or $\mathrm{I}^{+}$strain of $S$. typhimurium

For details, see text.

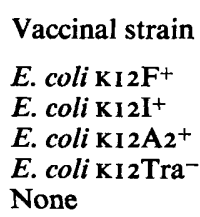

Vaccinal strain

None

$\begin{array}{ccc}\text { For details, see text. } \\ \text { No. of chickens vaccinated } \\ \text { Expt I } & \text { Expt } 2 & \text { Expt } 3 \\ 25 & 24 & 44 \\ - & - & 46 \\ 22 & - & 47 \\ 25 & 28 & 46 \\ \end{array}$

For significance, see Table I.
Percentage that died when infected with:

\begin{tabular}{|c|c|c|}
\hline \multicolumn{3}{|c|}{$\begin{array}{l}\text { Percentage that died when } \\
\text { infected with: }\end{array}$} \\
\hline $\mathbf{F}^{+}$strain & & rain \\
\hline Expt I & Expt 2 & Expt 3 \\
\hline $54.0 \dagger$ & $29.2 \dagger$ & $34 \cdot \mathrm{I} N S$ \\
\hline- & $=$ & $15.2 \dagger$ \\
\hline - & - & $19^{*} I^{*}$ \\
\hline $\begin{array}{l}95 \cdot 4 \\
100 \cdot 0 \mathrm{NS}\end{array}$ & $\begin{array}{l}82 \cdot \mathrm{I} \\
90 \cdot 0 \mathrm{NS}\end{array}$ & $\begin{array}{l}45 \cdot 7 \\
80 \cdot 4 \dagger\end{array}$ \\
\hline
\end{tabular}

vaccination with the $\mathrm{I}^{+}$or $\mathrm{A2}^{+}$strain, but not the $\mathrm{F}^{+}$strain, of $E$. coli KI2 significantly reduced the mortality resulting from infection with an $\mathrm{I}^{+}$strain of $S$. typhimurium (Table 2). In experiment 2 (Table I) and experiment 3 (Table 2) the mortality rate in the group of chickens vaccinated with the Tra- strain of $E$. coli KI 2 was significantly less than in the unvaccinated group.

In the majority of cases, all of the ten colonies isolated on MacConkey's agar from the livers of vaccinated and unvaccinated chickens that had died following infection with the $\mathrm{F}^{+}$strains of $S$. heidelberg and $S$. typhimurium were fully susceptible to the MS2 phage. Usually, half or more of the ten colonies examined from each of the chickens that died within three days of infection with the $S$. typhimurium $\mathrm{I}^{+}$strain were susceptible to the phage, but most colonies from chickens that died after this time were not.

\section{Slide agglutination tests}

Using undiluted antisera, the $\mathrm{F}^{+}$strain of $S$. heidelberg was agglutinated by the $\mathrm{F}^{+}$strain of $E$. coli $\mathrm{KI} 2$ antiserum but not by antisera to the $\mathrm{I}^{+}$or $\mathrm{A2}^{+}$strains of $E$. coli $\mathrm{KI}$. The $\mathrm{I}^{+}$ strain of $S$. typhimurium was agglutinated by an antiserum to the $\mathrm{I}^{+}$and $\mathrm{A2}_{2}^{+}$strains, but not to the $\mathrm{F}^{+}$strain, of $E$. coli $\mathrm{KI} 2$. 


\section{DISCUSSION}

The present investigation was undertaken as a prelude to the immunological study of transmissible pathogenic characters. Because of the poor selection methods that exist for their detection, the characters available for study are usually those whose efficiency of transfer is high, probably approaching that of F, I and A2. Because efficiency of transfer and degree of piliation are directly related, the immunity produced by the sex pili determined by the transfer factors of some of these pathogenic characters might, therefore, be of the order of that produced by F, I and A2 in the present investigation. If so, it would be more than sufficient to complicate some aspects of the immunological study of these characters. Should the genes determining such characters and pilus production be located on the same plasmid this complication would be difficult to overcome.

Whether sex pilus immunity is important under natural conditions is another matter. Most transfer factors apparently exist in a repressed state and, as a consequence, many $\mathrm{Tra}^{+}$bacteria may produce too few pili either to provoke a significant level of antibody or to react with such antibody in potential disease-producing situations.

The $\mathrm{I}^{+}$and $\mathrm{A2}_{2}^{+}$, but not the $\mathrm{F}^{+}$, strains of $E$. coli $\mathrm{KI} 2$ produced an immunity against the $\mathrm{I}^{+}$challenge strain of salmonella, and the $\mathrm{F}^{+}$strain, but not the $\mathrm{I}^{+}$and $\mathrm{A2}_{2}^{+}$strains, of $E$. coli $\mathrm{KI} 2$ produced an immunity against the $\mathrm{F}^{+}$challenge strain of salmonella; these results are in agreement with the results of the agglutionation tests. Our inability to demonstrate a relationship between $\mathrm{F}$ and $\mathrm{I}$ by either method confirms the observations of earlier workers using agglutination and other techniques to detect antibody.

We are grateful to Mrs Frances Richards for her capable technical help. Our thanks are also due to Dr P. M. Biggs, Miss Doreen Cooper, Mr J. G. Rowell and Mrs Margaret Webster for assistance in a variety of ways.

\section{REFERENCES}

BRAUN, W. \& Bonestell, A. E. (1947). Independent variations of characteristics in Brucella abortus variants and their detection. American Journal of Veterinary Research 8, 386-390.

Davis, J. E., Strauss, J. H., Jun. \& Sinsheimer, R. L. (1961). Bacteriophage MS2: another RNA phage. Science, New York 134, 1427.

HARDEN, V. \& MEYNELL, E. (I972). Inhibition of gene transfer by antiserum and identification of serotypes of sex pili. Journal of Bacteriology 109, 1067-1074.

Hardy, K. G., Meynell, G. G., Dowman, J. E. \& Spratt, B. G. (1973). Two major groups of colicin factors; their evolutionary significance. Molecular and General Genetics 125, 2 1 7-230.

HAYES, W. (1953). Observations on a transmissible agent determining sexual differentiation in Bacterium coli. Journal of General Microbiology 8, 72-88.

LAwn, A. M. \& MeYnell, E. (1970). Serotypes of sex pili. Journal of Hygiene 68, 683-694.

Lederberg, J., Cavalli, L. L. \& Lederberg, E. M. (1952). Sex compatibility in E. coli. Genetics 37, 720-730.

Meynell, G. G. \& LAwn, A. M. (I968). Filamentous phages specific for the I sex factor. Nature, London 2I7, I I 84-II86.

ØRSKov, I. \& ØRSKov, F. (1960). An antigen termed $\mathrm{f}^{+}$occurring in $\mathrm{F}^{+}$E. coli strains. Acta pathologica et microbiologica scandinavica 48, 37-46.

Smith, H. Williams \& Gyles, C. L. (1970). The relationship between different transmissible plasmids introduced by $\mathrm{F}$ into the same strain of Escherichia coli. Journal of General Microbiology 62, 277-285.

Smith, H. Williams \& Heller, E. D. (1973). The activity of different transfer factors introduced into the same plasmid-containing strain of Escherichia coli KI 2. Journal of General Microbiology 78, 89-99.

Smith, H. Williams \& LingGoOd, M. A. (1970). Transfer factors in Escherichia coli with particular regard to their incidence in enteropathogenic strains. Journal of General Microbiology 62, 287-299. 